\title{
Can Museums Find Male or Female Audiences Online with YouTube?1
}

\section{Mike Thelwall, University of Wolverhampton, UK}

Purpose: This article investigates if and why audience gender ratios vary between museum YouTube channels, including for museums of the same type.

Design/methodology/approach: Gender ratios were examined for public comments on YouTube videos from 50 popular museums in English-speaking nations. Terms that were more frequently used by males or females in comments were also examined for gender differences.

Findings: The ratio of female to male YouTube commenters varies almost a hundredfold between museums. Some of the difference could be explained by gendered interests in museum themes (e.g., military, art) but others were due to the topics chosen for online content and could address a gender minority audience.

Practical implications: Museums can attract new audiences online with YouTube videos that target outside their expected demographics.

Originality/value: This is the first analysis of YouTube audience gender for museums.

Keywords: YouTube; gender; museums; art galleries; social web; audiences.

\section{Introduction}

Public museums and art galleries conserve collections of artefacts, often related to a theme, such as art, culture, history and science. They employ a variety of strategies to attract visitors (e.g., O’Reilly and Lawrenson, 2014). A web presence may be used to advertise, provide richer detail for visitors, or give alternative access to those unable to attend in person (e.g., Coleman and Nankervis, 2015). Three quarters of 982 UK arts and cultural organisations believed that digital technologies helped them to fulfil their missions in 2015, with most (56\%) using YouTube as part of this (Nesta, 2015). Moreover, 29\% of museums and art galleries posted their own content to YouTube in 2016 (Visit Britain, 2016). Nothing is known about whether online content can help to attract new audiences, however, such as those from demographics that rarely visit.

Whilst many museums aim to serve the whole public (Quinlan-Gagnon, 2012), others target social issues such as gender and class inequalities (Spring, Smith, and DaSilva, in press). A museum may therefore wish to attract a demographic because it would not normally visit or because it is the target of an exhibition (e.g., Merriman, 2018). This paper focuses on gender and assesses whether YouTube museum videos can attract gendered audiences.

YouTube contains limited implicit public gender information for the traditional binary genders (male/female), although not for non-binary genders. Since this information is public it can be used to compare female/male audience ratios between museum videos. Public social media has been previously used to investigate museum-related online activities (Facebook questionnaires: Sundjaja, Gaol, Abdinagoro, \& Abbas, 2017), but not for YouTube on a large scale. The current paper investigates videos posted by 50 large museums for insights into their audience genders. It exploits the publicly available information in their comments for evidence that the proportions of females and males watching videos varies between museums. A positive result would suggest that museums could reasonably target audience genders on YouTube.

\footnotetext{
${ }^{1}$ Thelwall, M. (in press). Can museums find male or female audiences online with YouTube? Aslib Journal of Information Management.
} 


\section{Museums and gender}

For many people, attending a museum is a choice unless they visit as part of an organised trip or at the behest of friends or family members. When made, this choice is influenced by a person's interests, which is in turn influenced by their socialised gender identity. To compare museum videos online by audience gender it is therefore useful to understand why there are gender differences in the visitors to different types of museums. This review focuses on binary genders with apologies to non-binary genders, for which more research is needed.

\section{Gender and interests}

There are substantial (binary) gender differences in interests that may be primarily due to social pressures (e.g., Halpern and Perry-Jenkins, 2016; McHale, Kim, Dotterer, Crouter, and Booth, 2009; Kornienko, Santos, Martin, and Granger, 2016) and media gender stereotypes (e.g., Matthes, Prieler, and Adam, 2016). In psychology, gender differences in interests have been studied most in terms of toy choices by children. For example, one study showed that babies exhibited sharply gendered reactions to toys even prior to their development of gender identities (Alexander, Wilcox, and Woods, 2009). Together with human-like gendered toy choices in some primates (Hassett, Siebert, and Wallen, 2008) and pre-natal testosterone levels moderating gendered preferences (Hines, 2011; Swan, Liu, Hines, Kruse, Wang, Redmon, and Weiss, 2010), this gives evidence of a biological sex component to gendered interests. In particular, boys' interest in toys associated with spatial movement, such as wheeled trucks, appears to be a generic, but variable, human masculine trait (Hines, 2011). These initial tendencies then seem to be exacerbated by social processes, creating substantial gender divides in adulthood. Nevertheless, greater male interest in museums for things that move (e.g., cars, aircraft, spacecraft) may have a partially biological explanation.

More generally, social psychologists argue that for adults there seems to be a greater male interest in 'things' and a greater female interest in people ( $\mathrm{Su}$, Rounds, and Armstrong, 2009). Thus, museums and art galleries that naturally or deliberately relate to people or human dimensions may tend to attract more female visitors. Similarly, greater levels of male aggression (Bettencourt and Miller, 1996) and greater involvement in military careers may partly explain a greater male interest in military museums. Specialist museums for topics closely tied to other gendered careers (e.g., nursing) can also be expected to attract a corresponding gendered audience.

\section{Museum attendance and gender}

There is little public information or academic research about museum attendance by gender, and no systematic comparisons of museum audiences by type. This is a strange omission, given that there is extensive research into other gender issues within museums, including staffing (Callihan \& Feldman, 2018), as well as representations of gender and sexuality, gendered reactions to exhibits, and cases where non-male artists or traditions are ignored (Levin, 2010). Prior research has typically been qualitative, focusing on a single case, and theory-driven, interpreting that case in the light of a general sociological theory.

The little public information that exists about museum visitor genders suggests that a female majority is the norm. A survey of European museums found that most visitors were female (58\%), including for most individual museums. The gender breakdown varied from the National Museum of Estonia (63\% female) to the National Historical Museum of Athens (45\% female) (Bounia, Nikiforidou, Nikonanou, and Matossian, 2012). All six Northern Ireland museums in another survey had mostly female visitors, with the highest being $70 \%$ at the F.E McWilliam Gallery \& Studio (ANI, 2016). In New Zealand, women were the majority (58\%) of visitors to 37 museums and art galleries (Museums Aotearoa, 2017). Other 
museums with mostly female visitors include Cambridge University (59\% female) (TAA, 2014), Washington State History Museum in 2013 (64\% female) (Morey Group, 2013), West Highland Museum (local and regional history, Scotland) Visitors Survey 2016 respondents (56\% female) (OSSL, 2016), but not the Hong Kong Museum of History Permanent Exhibition (49\% female) (Actrium Solutions, 2016). There is less data on science museum visitors but females (47\%) had a lower attendance than males at Smithsonian science museums (Smithsonian, 2004, p.7).

Females often dominate art gallery attendees. Females were a majority (66\%) of Minneapolis Institute of Arts attendees in 2001 (Cincinnatus, 2001, p.12) and of Smithsonian arts museum attendees in 2004 (59\%) (Smithsonian, 2004, p.7). Surveys of citizen participation in the arts 2002-2012 in the United States showed that the majority had visited an art gallery or museum at least once as a child. In 2012, a fifth (21\%) of adults had visited art galleries or museums in the previous 12 months (Silber and Triplett, 2015: Figure 1-13). Of these visitors, 57\% were female (Silber and Triplett, 2015: Figure 1-15). Females were the majority of attendees at all arts events in the survey, including almost two thirds of ballet and book reading attendees (Silber and Triplett, 2015: Figure 1-10).

In summary, the above analyses of visitor data suggest that females seem to attend general museums and art galleries the most, but males may be more likely to visit science museums. Due to the lack of public evidence of museum attendances by gender for the many different types it is impossible to be sure of the audience gender balances at a finer grained level of detail. Nevertheless, likely gender imbalances for other museum types can be inferred from other information about gendered interests. From data about gendered participation rates in academic specialisms (Tellhed, Bäckström, \& Björklund, 2017), it seems likely that males would be the majority for physical (but not biological) science, technology, space, aircraft, and vehicle museums (the latter two because of their engineering associations). Males would also be more likely to attend aircraft and vehicle museums because of their hypothesised interest in things, as discussed above. Males also seem to be more likely to attend military museums because of greater interest in the military as a career, as well as recreational violence (e.g., DiPietro, 1981). From academic specialism participation rates (Tellhed, Bäckström, \& Björklund, 2017), females may be more likely to attend museums focusing on humans (e.g., social history, occupational-focused museums) or biological sciences (e.g., natural history). From the hypothesised people-orientation of female interests, they may also be more likely to attend living history museums. In addition, there may be a general gender bias over all types of museums if, for example, females are more likely to attend as part of a family group.

\section{Gendered activities within museums}

Gendered behaviour has been noticed within museums for children, giving evidence of the pervasiveness of gender socialisation and the difficulty of combatting it within a museum experience. A review of early research found that girls cooperated more at science museums whereas boys were more willing to explore alone (Diamond, 1994). At the Center of Science and Industry (COSI) in Columbus, Ohio, 419 children were observed playing with five exhibits, with overall gender differences in the ways that they interacted with them that followed gender stereotypes. For example, some girls used paint as makeup and displayed behaviour classed as nurturing (in the Animal Lab) whereas some boys engaged in play fighting with the water jets (Kremer and Mullins, 1992). The authors argued that museums need to work to ensure that both genders have a reasonable chance of picking up useful skills, such as nurturing.

A study of how boys and girls talked about animal exhibits found many similarities but with boys being more concerned with formal naming whereas girls were more likely to 
express opinions (Tunnicliffe, 1998). At a cultural heritage museum in Australia, boys and girls tended to interact differently with the exhibits (Sutcliffe and Kim, 2014). Such museums can encode gender biases in the exhibits are selected and described, which may alienate or mislead visitors (Heitman, 2017; Anderson and Winkworth, 2014; Machin, 2008). Removing gender bias stereotyping is not enough, however (see also: Ramey-Gassert, 1996; Dancu, 2010; Haliliuc, 2013).

Museums with a focus that appeals more strongly to one gender may not provide an engaging experience to other visitors. Observations of adults at a baseball museum in the United States suggested that females tended to find exhibits less personally relevant (Blinde and McCallister, 2003). Art galleries fit awkwardly in this context. Despite the majority female attendances at art galleries, their collections tend to be dominated by male artists, whose works tend to be more valued (Christensen, 2016). There is no gender difference in the average amount of time (21 seconds) spent viewing each artwork, however (Smith, Smith, and Tinio, 2017). A feminist pedagogy initiative for gender-based consciousness raising based around an art gallery in Canada (Spring, Smith, and DaSilva, in press) shows that gender issues can be addressed in museums that attract mostly female visitors.

Bulstrode Park in the UK is an eighteenth-century example of a female-oriented museum. It was designed by a woman to appeal to (rich) women of the time, with an emphasis on artistic considerations and handicrafts (Pelling, 2018). Although museums of that period were largely operated by and for men, women played an increasingly important role in British museums over the next two centuries, exerting increasing influence (Hill, 2016). Gender biases in museum professionals and leadership nevertheless remain an important contemporary concern (Baldwin and Ackerson, 2017).

For science, a historically male-associated interest, an investigation into the long-term impact of visiting the UK National Space Centre found that both girls and boys experienced increased positivity towards science in the short term but that that its impact was longer term for girls (Jarvis and Pell, 2005). Participation in an educational programme at a science museum also apparently had a more positive impact on female attendees (Price, Kares, Segovia, and Loyd, in press), raising the possibility that museums can help to address the current gender divide in some areas of science (STEM subjects).

Overall, then, there is evidence of gender differences in museum-related interests and visiting by type and in behaviour within museums but nothing is known about gender in the context of museum web presences.

\section{Museums, YouTube and gender}

From a cultural perspective, videos and films are essential to provide a record of activities that naturally involve motion or integrated sound and vision (Pietrobruno, 2014), such as the Chogān horse-riding game with music and storytelling ${ }^{2}$. Placing such videos online in a public space, such as YouTube, helps to fulfil a museum's public access mission. Videos can also enrich online museum presences when they are not needed as a public record of an activity. For example, a video can rotate perspective to give a three-dimensional impression of an object for online visitors. Even an intrinsically flat artefact, such as a photograph, could be enriched by a video describing the creation process or an interview with the artist. Whilst high quality videos are expensive and time consuming to create, YouTube offers a free longterm hosting solution. An investment may therefore have long term benefits, especially if the content can attract new demographics, such as gender(s) that rarely visit offline.

Video view counts can be used as evidence of audience size (Fernandes, 2018) and comments posted to these videos as feedback about which videos or artefacts are interesting

\footnotetext{
${ }^{2}$ https://ich.unesco.org/en/RL/chogan-a-horse-riding-game-accompanied-by-music-and-storytelling-01282
} 
as well as information about how the public reacts to them. Like web crowdsourcing, YouTube comments have the dual benefits of participation and feedback (e.g., Eccles, 2018; Oomen, Gligorov, and Hildebrand, 2014; Eccles and Greg, 2014). Nevertheless, they have rarely been used to analyse audience demographics and never to compare different museum audiences. Although one study has claimed that a museum YouTube channel had a surprisingly high proportion of male viewers (Fernandes, 2018), there are no prior gender analyses of YouTube for museums. This section gives a brief overview of museum-related YouTube research for additional background, followed by some unrelated studies of gender on YouTube.

An old analysis of Portuguese museum social web presences found YouTube to be one of the most popular (Pedro, 2010), confirming that YouTube is not a novelty for museums. A qualitative investigation of comments on videos about a Cambodian genocide museum that were not created by the museum showed that these can give insights into visitors' reactions and locals' disagreements with visitors' interpretations (Benzaquen, 2014). A paper about Australians forcibly removed from their parents compared comments on the National Museum of Australia website to YouTube videos. It showed, for example, that museum-based content is implicitly framed by its context within the museum (Adkins \& Hancox, 2014). An analysis of the Guggenheim Foundation's YouTube Play Biennial competition investigated the 25 submitted art videos (with over 25 million views in total) selected by a Guggenheim jury (López Martín, \& Morgado Aguirre, 2015). This showed that a high-profile art gallery could generate huge attention through YouTube, although in this case for video works submitted by (professional) artists. Overall, however, these studies give little insight into good practice in YouTube for museums or gender differences for museums within the site.

Away from museums, gender has been investigated on YouTube in many different contexts. A quantitative analysis of comments on videos related to different dance styles showed that audience genders varied greatly by style and there were also gender differences in the types of comments made. For example, females were more likely to post supportive messages in comments (Thelwall, 2018). An investigation of gender differences in comments on YouTube science channels (with similar methods to the current paper) confirmed the positivity bias of female commenters and the potential for substantial gender differences in audiences for YouTube channels with similar themes (Thelwall \& Mas-Bleda, 2018). A much larger scale similar analysis of science channels found that female presenters were more likely to be the subject of sexual comments and negativity (Amarasekara \& Grant, in press), although the prior study had found males to be the more likely target of criticism (Thelwall \& Mas-Bleda, 2018). Negativity towards female presenters was also found by a comparison of two YouTube comedy channels (Döring \& Mohseni, in press). In summary, prior quantitative studies have found gender dimensions to YouTube commenting and audiences, but suggest that hostility to females may sometimes be a problem.

\section{Research Questions}

This study assesses whether museums can attract gendered audiences through YouTube, in the sense of viewers that are substantially more from one gender than average of the museum type on YouTube. This is primarily addressed through the first research question. The second research question investigates why gender differences might be possible by identifying topics of interest that differ between males and females. The Discussion section following the results analyses whether the answers to the research questions are largely determined by the theme of a museum. If not, then museums might be able to target audiences by gender through YouTube. 
- RQ1 (quantitative): Are there substantial differences between YouTube museum channels in the ratio of females to males that they attract, and is this also true for similar museums?

- RQ2 (mixed qualitative/quantitative): Are there gender differences in the topics discussed by YouTube museum channel video commenters overall (RQ2a) and within museums (RQ2b)?

\section{Methods}

The research design was to identify a set of popular museum YouTube channels, download the comments on the videos in each channel and analyse commenter genders and gender topics for each one. A relatively large-scale comparison is essential for investigating audiences because YouTube has its own demographic biases so that face-value interpretations of its statistics can be misleading (Haran and Poliakoff, 2011). A quantitativeled mixed methods triple text analysis approach was used: a qualitative investigation of the output from three complimentary quantitative analyses. The first method concerns the comment authors and the next two involve the comment text. Video commenters were analysed rather than video viewers because no public information is available about most video viewers. The methods are an adapted subset of those outlined in a recent article (Thelwall, 2018). The analysis steps were as follows.

- Comment authors genders: The ratio of female to male commenters was calculated for each museum YouTube channel so that audience genders could be compared (RQ1).

- Overall gendered terms: The individual words that are most likely to occur in female comments compared to male comments across all museums were found, and vice versa. This can point to the overall museum-related topics that are most interesting to these two genders (RQ2a).

- Within museum gendered terms: The individual words that are most likely to occur in female comments compared to male comments within individual museums were found, and vice versa. This can point to gender differences that tend to be crossmuseum and could include narrower topics, themes or issues (RQ2b).

\section{Data}

\section{Museum set}

Lists of visitor numbers for museums in English speaking nations were used as a starting point to identify a suitable collection of popular museums to analyse. English speaking was a requirement for common ground with the gender and topic detection methods. Popular museums were chosen because these are more likely to have extensive YouTube collections, allowing more powerful and extensive analyses. Museum names from the lists were searched in YouTube to find associated channels. Channels were rejected if significant numbers of comments were not in English (for the text content analysis steps) or if there were less than 50 comments in total (for the statistical comparisons). To find additional museums with popular channels even if they are not popular offline, the term "museum" was searched in YouTube and matching channels investigated. Only museums with a physical presence were accepted. This step was chosen because there were YouTube-only museums, such as the Museum of Working Miniatures, for which the name "museum" seemed to be a marketing choice rather than an accurate description. There are some genuine virtual museums with a digital preservation and curation mission, such as Rhizome, but none were identified during the YouTube searches. 
The above process identified 50 YouTube museum channels owned by physical museums with comments mainly in English. They were from the USA, UK, Canada, Australia and New Zealand.

\section{Comment collection}

The free software Mozdeh (http://mozdeh.wlv.ac.uk) was used to download a complete set of videos from each channel with the YouTube API. For each video, Mozdeh downloaded all available comments during February 14-15, 2018. For videos with many comments, only the most recent approximately 150 can be downloaded with the YouTube API and the older comments were ignored. This is a limitation but also an advantage because it prevents individual popular videos from dominating the results. In practice, the 150 restriction is unavoidable because it originates with YouTube and the only alternative, manually copying and pasting comments from the YouTube website, is impractical for the volume of comments gathered here.

Each comment has associated metadata, such as its author username and creation date. When the same person had commented multiple times on a video, only their first comment was retained to avoid their opinions dominating the results (an option in Mozdeh). The final dataset had 262,466 comments from unique commenters on videos from the YouTube channels of 50 museums.

\section{Gender detection}

YouTube does not report the gender of viewers or commenters but it is possible to infer the gender of some commenters from their usernames. This information was used as a proxy for audience gender information.

Each username was segmented into two parts, where possible, at the first apparent word boundary. This was either a space, a number, or a transition from lowercase to uppercase (e.g., Sarah Smith, Nicki99, InderjeetUppal). The first segment was then compared with dictionaries of predominantly male or female names. First names in the female dictionary are employed at least $90 \%$ of the time by females in the US 1990 census. A similar rule was applied for males and the titles Mr, Mrs, Ms were added as surrogate first names. This process resulted in $29 \%$ of the commenters being assigned a gender. The remainder were ignored for the gender analysis, leaving 74,815 comments with author genders.

This process produces some errors. In addition to minority gender names (e.g., a male Andrea), people may adopt a cross-gender nickname, may be non-binary, or may use their last name as the first part of their username (e.g., Scott, Jackson). A prior investigation suggested that the method usually identifies gender correctly but if a set of commenters was $50 \%$ male then this method would estimate it at $53 \%$ male $^{3}$, giving a small male bias. This was factored out of the analyses, when possible, and, since it is the same for all museums, does not greatly affect comparisons between museums. Since the gender detection is usually correct, for the minority of cases where it detects a gender, the term frequency comparisons discussed below work but are less statistically powerful than for more accurate and/or comprehensive gender detection.

\section{Analysis}

\section{RQ1: Museum channel commenter gender ratios}

The ratio of male to female commenters was calculated for each museum channel. Genders were determined using the heuristics described above and counting each video commenter

\footnotetext{
${ }^{3}$ https://doi.org/10.6084/m9.figshare.5688622
} 
only once to focus on the number of participants of each gender. The likely over-estimation of males was corrected for by multiplying the number of male commenters by 50/53 before the calculation. Similarly, the likely under-estimation of females was corrected for by multiplying the number of female commenters by 50/47 before the calculation.

\section{RQ2a: Overall gendered terms}

Overall gendered terms were detected by finding words that occurred in a higher percentage of female comments than of male comments, and vice versa. For example, if "like" occurred in $5 \%$ of the female-authored comments and $3 \%$ of the male-authored comments then it would be classed a female-gendered term. Since these proportions can differ by chance, a $2 x 2$ chi-square test was used to judge whether a gender difference was statistically significant. This process was conducted systematically as follows.

A list was made of all 56,618 words in all comments. For each word, the number of male-authored and female-authored comments containing it was deduced, and a 2x2 chisquare value calculated from these numbers. The words were then listed in decreasing order of chi-square value and the Benjamini-Hochberg method (Benjamini and Hochberg, 1995; see also: Holm, 1979) used to select statistically significant terms. The Benjamini-Hochberg method controls the risk of one or more false positives (i.e., falsely concluding that a term is gendered) when running multiple individual tests. It requires higher values of the test statistic (the chi-square value) to be significant, and uses an efficient procedure to maximise the likely number of true positive results, whilst controlling the likelihood of one or more false positives to, typically, $5 \%, 1 \%$ or $0.1 \%$. For the current paper, terms were regarded as gendered if reported as such by the Benjamini-Hochberg test at the $0.1 \%$ level.

The above was achieved with Mozdeh by selecting the female filter and clicking the Mine Associations button. This was repeated for the male filter and the results of both copied to Excel. To investigate each individual term for context, it was entered as a query in Mozdeh to find comments containing the term and the Mine association buttons used to find other words that often occur alongside it in comments.

\section{RQ2b: Gendered terms within each museum channel}

The above procedure was repeated within each museum channel to find words that were gendered within it. For example, if $6 \%$ of the female authored comments and $4 \%$ of the male authored comments from a channel contained the term "husband" then it would be regarded as a female gendered term for that channel. As above, multiple comments from the same user and comments with unknown user genders were excluded. Multiple comments from the same user were excluded for two reasons. First, having a common factor in multiple comments (the same person) invalidates the statistical tests used. Second, allowing multiple comments gives the possibility that a single active user or troll would dominate the results, shedding no light on the underlying gender differences. The same justifications have been previously used for quantitative YouTube comment analysis (Thelwall, 2018).

To identify terms that tended to be gendered within the comments of multiple museums, the top 10 male gendered and top 10 female gendered terms were extracted from each channel. Next, the gendered term lists from the 50 channels were combined and the terms that occurred in the top 10 for at least 5 lists were retained as the within-channel gendered terms, using the chi-square statistic for the ranking. The figures of 10 and 5 were chosen heuristically to give the most informative results. This approach was used rather than a statistical test for each individual term (e.g., Benjamini-Hochberg) because the requirement for a term to be in the top 10 of 5 lists reduces the chance of false positives. 


\section{Results and discussion}

\section{RQ1: Comment author genders by museum}

There is an enormous difference in the gender composition of audiences for YouTube museum channels in terms of estimated commenter genders (Table 1). The number of females for every male varies from 0.07 (14 males for every female) to over 6 . In the extreme case, the number of female commenters per male commenter is 94 times higher for National Museums Liverpool than for The Tank Museum. It is clearly possible for museums to attract either a mostly male audience or a mostly female audience through YouTube.

In contrast to the female majority of museum visitors, only 6 of the 50 channels have mostly female commenters. Four of these are art galleries, but there are many art gallery channels with a male commenter bias. The most male gendered museums cover traditionally male topics, including military history, space, and computers. Thus, in general, museums may attract genders online that correspond to the genders that they attract offline, except with a male bias.

Table 1. The number of comments from commenters with an inferred gender and the ratio of female to male commenters for 50 popular YouTube museum channels. Data from February 2018. Museums are in the USA unless stated or clear from the name.

\begin{tabular}{|l|r|r|}
\hline Name & $\begin{array}{c}\text { Gendered } \\
\text { comments }\end{array}$ & F/M \\
\hline National Museums Liverpool, UK & 1716 & 6.59 \\
\hline Smithsonian NMAfA (National Museum of African Art) & 38 & 2.45 \\
\hline Fine Arts Museums of San Francisco & 97 & 1.43 \\
\hline MCA Australia (Museum of Contemporary Art) & 27 & 1.08 \\
\hline Museum of Fine Arts, Boston & 219 & 1.07 \\
\hline National Museums Scotland & 45 & 1.05 \\
\hline Guggenheim Museum (art) & 166 & 1.02 \\
\hline Newfields: A Place for Nature \& the Arts (Indianapolis) & 336 & 0.93 \\
\hline National Gallery of Victoria, Australia & 48 & 0.85 \\
\hline Museum of Modern Art (Manhattan) & 1411 & 0.84 \\
\hline National Museum of African American History and Culture & 88 & 0.69 \\
\hline Getty Museum (Western art) & 324 & 0.69 \\
\hline The National Gallery, London, UK & 381 & 0.64 \\
\hline The Art Institute of Chicago & 183 & 0.63 \\
\hline National Museum of American History & 343 & 0.63 \\
\hline Imperial War Museums, UK & 298 & 0.60 \\
\hline National Gallery of Art, UK & 77 & 0.57 \\
\hline Saatchi Gallery (art, UK) & 25 & 0.56 \\
\hline Australian Centre for the Moving Image & 128 & 0.56 \\
\hline Corning Museum of Glass & 2281 & 0.56 \\
\hline Courtauld Institute of Art, UK & 34 & 0.55 \\
\hline Museums Sheffield, UK & 49 & 0.53 \\
\hline Victoria and Albert Museum (London, UK) & 692 & 0.53 \\
\hline LACMA - Los Angeles County Museum of Art & 154 & 0.51 \\
\hline SAAM/Renwick Gallery [Smithsonian American Art Museum] & 0.50 \\
\hline
\end{tabular}




\begin{tabular}{|l|r|r|}
\hline Natural History Museum, London, UK & 374 & 0.49 \\
\hline Brooklyn Museum (art) & 478 & 0.48 \\
\hline Tate (art, UK) & 2243 & 0.47 \\
\hline Cooper Hewitt, Smithsonian Design Museum & 167 & 0.45 \\
\hline Horniman Museum and Gardens, UK & 13 & 0.44 \\
\hline Museum of Contemporary Art LA MoCA & 3568 & 0.43 \\
\hline Museum of London, UK & 73 & 0.43 \\
\hline National Portrait Gallery, UK & 39 & 0.39 \\
\hline The Metropolitan Museum of Art, New York & 995 & 0.38 \\
\hline San Francisco Museum of Modern Art & 113 & 0.38 \\
\hline Walker Art Center & 592 & 0.37 \\
\hline Royal Ontario Museum, Canada & 114 & 0.37 \\
\hline Museum of the Bible, Washington DC & 315 & 0.36 \\
\hline Queensland Art Gallery/GoMA, Australia & 182 & 0.35 \\
\hline Penn Museum (Archaeology and Anthropology) & 858 & 0.32 \\
\hline The British Museum & 3339 & 0.32 \\
\hline Science Museum Group, UK & 404 & 0.27 \\
\hline Smithsonian (group of museums) & 31899 & 0.27 \\
\hline Museum of New Zealand Te Papa Tongarewa & 1940 & 0.21 \\
\hline Royal Museums Greenwich (space, maritime, art), UK & 78 & 0.20 \\
\hline American Museum of Natural History & 9922 & 0.19 \\
\hline Computer History Museum, California & 1719 & 0.16 \\
\hline Smithsonian National Air and Space Museum & 992 & 0.12 \\
\hline National Museum of the Royal Navy, Portsmouth, UK & 42 & 0.11 \\
\hline The Tank Museum, Bovington, UK & 5104 & 0.07 \\
\hline
\end{tabular}

\section{RQ2a: Overall gendered terms}

The terms that were female gendered at the $0.1 \%$ level for all museum channels combined were grouped into themes by reading comments containing the terms and conducting followup word association tests on them (Table 2). The themes partly reflect traditionally female interests, and perhaps the recent success of vampire romances. Personal expression (including personal pronoun use: Newman, Groom, Handelman, and Pennebaker, 2008) and positive sentiment (Thelwall, Wilkinson, and Uppal, 2010) are female-associated communication behaviours. 
Table 2. Themes extracted from terms that were female gendered at the $0.1 \%$ level by exploring their context in comments. The data is the combined comment set from all videos. Singular and plural terms are merged.

\begin{tabular}{|l|l|}
\hline Theme & Gendered terms within the theme \\
\hline Clothes & $\begin{array}{l}\text { dress, layer, pocket, dressed, clothe, wear, corset, dresses, jeans, } \\
\text { knicker, clothing, wearing, century, bra, outfit, gown, summer, boob, } \\
\text { wore, Victorian, pant, fashion, skirt, hair, Dita, Eliza, Hamilton, } \\
\text { bathroom, pee, uncomfortable, maid }\end{array}$ \\
\hline Positive sentiment & $\begin{array}{l}\text { beautiful, love, thank, cute, omg, so, loved, amazing, wonderful, } \\
\text { gorgeous, adorable, aww, wow, fascinating, lovely, sharing }\end{array}$ \\
\hline Personal & I, my, am, wish, watching \\
\hline Females & she, her, women, girl \\
\hline Art & art, artist, glass, Corey (painting instructor) \\
\hline Baby lion & cub \\
\hline Shop & Woodprix \\
\hline Vampire bats & bats [How Vampire Bats Suck Blood for 30 Minutes Unnoticed] \\
\hline
\end{tabular}

Male comments (geometric mean 12.4 words per comment, 95\% confidence interval: (12.3, 12.5)) were longer than female comments (geometric mean 10.6 words per comment, $95 \%$ confidence interval: $(10.4,10.8))$, on average. Because of this, some general words were more likely to be male-oriented. The terms that were male gendered at the $0.1 \%$ level were grouped into themes in the same way as for female terms (Table 3). The themes follow traditional male interests as well as argument. Online bullying (Li, 2006) and negativity (Alonzo and Aiken, 2004) are male-associated behaviours.

Table 3. Themes extracted from terms that were male gendered at the $0.1 \%$ level by exploring their context in comments. The data is the combined comment set from all videos. Singular and plural terms are merged.

\begin{tabular}{|l|l|}
\hline Theme & Gendered terms within the theme \\
\hline Military & $\begin{array}{l}\text { tank, gun, war, German, Tiger, round, force, plane, bullet, } \\
\text { Soviet, aircraft, turret, Sherman, shot, Fletcher (name), Jingle } \\
\text { (name) }\end{array}$ \\
\hline Argument & $\begin{array}{l}\text { nothing, say, shit, far, not, no, theory, if, point, likely, evidence, } \\
\text { but, fact, fuck, argument }\end{array}$ \\
\hline Universe history & year, simulation, earth, exist, hundred, speed, existence \\
\hline Science & science, number, thousand, mile, light \\
\hline Religion & evolution, bible \\
\hline Space & space, universe \\
\hline Men & man, guy \\
\hline Cars & car \\
\hline Engines & engine \\
\hline Games & game \\
\hline Geopolitics & Europe \\
\hline Computing & system \\
\hline Things & the, a, an, it, on, in, out [typically used to discuss an object] \\
\hline Nothing - length-related & $\begin{array}{l}\text { of, as, or, which, by, is, there, be, than, we, that, any, at, with, } \\
\text { and, from, only, has, into, to, then, one, another, most }\end{array}$ \\
\hline
\end{tabular}




\section{RQ2b: Within channel gendered terms}

Within video channels, terms that were most often female associated relate to expressing positive sentiment or females (Table 4). The latter suggests that museum channels might attract more females by having content about women.

Table 4. Terms that are in the top 10 male or female gendered terms in at least 5 of the 50 YouTube channels, together with the percentage of these channels in which the term is female-oriented. Qualification: over $50 \%$ female channels.

\begin{tabular}{|l|r|r|l|}
\hline Term & Channels & Female \% & Comment \\
\hline love & 16 & $100 \%$ & Positive sentiment \\
\hline thank & 13 & $100 \%$ & Positive sentiment \\
\hline beautiful & 9 & $100 \%$ & Positive sentiment \\
\hline amazing & 7 & $100 \%$ & Positive sentiment \\
\hline she & 11 & $91 \%$ & Female-oriented \\
\hline her & 9 & $89 \%$ & Female-oriented \\
\hline loved & 6 & $83 \%$ & Positive sentiment \\
\hline so & 10 & $80 \%$ & Positive sentiment \\
\hline go & 5 & $80 \%$ & Positive sentiment (wish I could go) \\
\hline interesting & 5 & $80 \%$ & Positive sentiment \\
\hline work & 6 & $67 \%$ & Positive sentiment/Art (work of art) \\
\hline make & 5 & $60 \%$ & Multiple \\
\hline see & 7 & $57 \%$ & Multiple \\
\hline video & 9 & $56 \%$ & Multiple \\
\hline
\end{tabular}

Male-associated terms within channels are often about males or things or are associated with arguments (Table 5). More content about men and objects may therefore attract a larger male audience. 
Table 5. Terms that are in the top 10 male or female gendered terms in at least 5 of the 50 YouTube channels, together with the percentage of these channels in which the term is female-oriented. Generic length-related terms are excluded. Qualification: under $50 \%$ female channels.

\begin{tabular}{|l|r|r|l|}
\hline Term & Channels & Female \% & Comment \\
\hline on & 8 & $0 \%$ & Thing-oriented \\
\hline he & 6 & $0 \%$ & Male-oriented \\
\hline his & 6 & $0 \%$ & Male-oriented \\
\hline would & 6 & $0 \%$ & Argument \\
\hline one & 5 & $0 \%$ & Mixed \\
\hline what & 11 & $9 \%$ & Argument \\
\hline not & 8 & $13 \%$ & Argument \\
\hline we & 7 & $14 \%$ & Argument (we can see...) \\
\hline but & 6 & $17 \%$ & Argument \\
\hline people & 5 & $20 \%$ & Argument (people demand...) \\
\hline an & 12 & $25 \%$ & Thing-oriented \\
\hline art & 6 & $33 \%$ & Art \\
\hline your & 10 & $40 \%$ & Argument (people demand...) \\
\hline like & 5 & $40 \%$ & Argument/positive sentiment \\
\hline
\end{tabular}

\section{Discussion: Museum theme vs. online audience gender}

This study is limited by exclusion of smaller museums and the focus on commenters, which are a small and biased subset of YouTube users. It is restricted to museums with English language comments in YouTube, but cultural practices may be different in non-English countries. It only investigates males and females, and is based on guessing their genders from their names. It also does not address the context in which the videos are viewed. For example, some videos might enhance the visitor experience whilst others might be watched by people that do not intend to visit. Low representation of one gender for a museum YouTube channel does not necessarily mean that the channel is unattractive to that gender. This is because one or more of its videos might instead be highly attractive to another gender, dwarfing the numbers for the remaining genders. The analysis is also limited by the lack of public museum audience demographics (Merriman, 2018), so that it is impossible to compare the YouTube audience to physical visitors by gender.

Whilst it is clear from Table 1 that there are huge gender differences in the viewers for museums on YouTube, some analysis is needed to decide if and why the same is true for museums with similar types. The rest of this section relates audience genders to museum themes, seeking evidence about how some museum videos have attracted viewers with a gender balance that is untypical for the museum type.

There are several examples in Table 1 of museum channels with unexpected gender balances amongst their commenters. The American Museum of Natural History attracted 5 male commenters for every female commenter, which seems to be a high proportion of males for a natural history museum, especially compared to the Natural History Museum, London (2 male commenters per female commenter). The greater American Museum of Natural History male orientation was driven by religion-vs.-science arguments and its coverage of space issues (e.g., The Known Universe by $\mathrm{AMNH}^{4}$ ). The Museum of New Zealand Te Papa Tongarewa, which incorporates natural, social and cultural history as well as art, also had a

\footnotetext{
${ }^{4}$ https://www.youtube.com/watch?v=17jymDn0W6U
} 
male commenter bias (5 to 1). Its comments included many religion-related arguments, with the term evolution occurring in $19 \%$ of all gendered comments. Thus, in both of these cases, the high proportion of males commenting was generated by an issue (religion) that may be seen as tangential to the role of the museum. Thus, these cases do not give evidence of an unusual gender balance for the museum topic.

National Museums Liverpool attracted a large female audience through its video Getting Dressed in the $18^{\text {th }}$ Century ${ }^{5}$, with 3.6 million views. This was by far the most female gendered audience of any popular video in the dataset. This group of museums includes art galleries (Lady Lever Art Gallery, Sudley House, Walker Art Gallery), the presumably maleoriented Merseyside Maritime Museum, as well as the International Slavery Museum, the Museum of Liverpool and the World Museum. Thus, through this video, National Museums Liverpool has reached a particularly large online female audience for any type of museum, whether deliberately or not. Comments on this video were relevant and therefore the channel does give evidence of an unusual gender balance (a very high proportion of females) for the topic.

The Imperial War Museums channel has attracted a relatively high proportion of female commenters (although low in total) for a military museum. This seems to be due to its inclusion of content related to home life in war (e.g., Rationing In Britain ${ }^{6}$ ) rather than a focus on the machines of war, in contrast to those with machine-based themes, such as tank museums. The Imperial War Museums (see also: Loxham, 2015) explore "conflict and its impact on people's lives" (iwm.org.uk), indicating that the online content follows the offline strategy of engaging with the human side of war, which may be a deliberate attempt to appeal to a larger female audience. It has become normal for military museums to pay some attention to the ethical and wider dimensions of war (Watson and Massie, 2015), but the Imperial War Museums seem to go further than most. In this context, it is not clear whether its relatively female YouTube presence reflects its offline visitor demographics. Nevertheless, its YouTube presence is clearly female-friendly for its type. Thus, this case does again give evidence of an unusual gender balance (a relatively high proportion of females) for the topic.

Modern art museums had considerably different gender splits, again giving clear evidence that a museum's type does not fully determine its YouTube audience gender. The most female-oriented audience was for the Museum of Modern Art (Manhattan), which had a focus on painting. The Museum of Contemporary Art LA MoCA had one of the most maleoriented art gallery audiences. It had music themes in its Art + Music section, including a Bjork music video, with almost 4 million views ${ }^{7}$, using "the earth's geology is a metaphor for human relationships”. It also had a collection of videos, such as The Art of Punk - Black Flag - Art + Music $^{8}$ (300,000 views), analysing, through interviews with band members, the graphic art side of punk bands that presumably had mainly male audiences (Andrews, 2014). Other punk bands covered included Crass and The Dead Kennedys. Thus, this museum is addressing an aspect of art in a way that could be expected to attract a male audience and fits with the musical tradition of its host city. Videos about street art also attracted a male audience, "Where others see blight, these artists see a canvas"9. Again, this case does give evidence of an unusual gender balance (a relatively high proportion of males) for the topic.

In summary, whilst audience gender for a museum tends to be related to its topic overall (Table 1), it can be greatly influenced by decisions about the content to present in YouTube, or the individual museum collection or strategy. The evidence therefore suggests

\footnotetext{
${ }^{5}$ https://www.youtube.com/watch?v=UpnwWP3fOSA

${ }^{6}$ https://www.youtube.com/watch?v=09wNJ78S2GY

${ }^{7}$ https://www.youtube.com/watch?v=ZM80F_J-QHE

${ }^{8}$ https://www.youtube.com/watch?v=N0u04EqNVjo

${ }^{9}$ https://www.youtube.com/watch?v=fHF1huG-qZc
} 
that a museum can find a predominantly male or female audience by generating suitable content.

\section{Conclusions}

The male majority of YouTube commenters for most channels contrasts with the apparent female majority of art gallery visitors, which form half of the museums analysed here. It is not clear whether this is due to a greater male tendency to comment on videos or whether it reflects a genuine online audience shift. If the latter is true, then YouTube is a good way for art galleries to reach a male audience. Nevertheless, the Liverpool example shows that YouTube can help a museum to reach an extremely large female audience, although it will be difficult to imitate the success of Liverpool. Two other examples show that museums can attract disproportionately many males or females for the museum type. Thus, museums are not constrained by their type about the audience genders that they can attract. The possibility to target online audiences by gender is an important practical implication of this research for science museums that seek to attract a larger female audience.

From a more theoretical perspective, the ability for museums to target genders online does not challenge theories about gender differences in interests that may lead to gendered museum attendances, as discussed in the literature review. Instead, as the individual YouTube examples show, and museum curators probably know offline, audience genders can be targeted by creating high quality content that addresses an aspect of the museum that is of greater interest to one gender.

In practice, good quality online content is expensive to create and does not always reach an audience because of competition for online attention. Nevertheless, since some museums have shown through their online presences that there is potential to reach new audiences and to target gender-related objectives, this option should be considered in the future when museums wish to target particular demographics.

\section{References}

Actrium Solutions (2016), "Hong Kong Museum of History permanent exhibition visitor survey 2016”, available at: http://hk.history.museum/documents/54401/4476638/Survey\%2BReport_Eng.pdf (accessed 20 June 2018).

Adkins, B., \& Hancox, D. (2014), "The role of the internet in testimony: the case of the 'Forgotten Australians'”, Media, Culture \& Society, Vol. 36 No. 8, pp. 1151-1167.

Alexander, G. M., Wilcox, T., \& Woods, R. (2009), "Sex differences in infants' visual interest in toys", Archives of Sexual Behavior, Vol. 38 No. 3, 427-433.

Alonzo, M., \& Aiken, M. (2004), "Flaming in electronic communication”, Decision Support Systems, Vol. 36 No. 3, pp. 205-213.

Amarasekara, I., \& Grant, W. J. (in press), "Exploring the YouTube science communication gender gap: A sentiment analysis”, Public Understanding of Science.

Anderson, M., \& Winkworth, K. (2014), "Museums and gender: an Australian critique”, Museum International, Vol. 66 No. 1-4, pp. 127-131.

Andrews, C.R. (2014), “Punk has a problem with women. Why?”, available at: https://www.theguardian.com/music/musicblog/2014/jul/03/punk-has-a-problem-withwomen-why (accessed 20 June 2018).

ANI (2016), “Northern Ireland museums visitor profiling project: Final report”, available at: https://www.nimc.co.uk/research-and-publications/download-publication/17/museumvisitor-profiling-final-report-august-2016.pdf (accessed 20 June 2018). 
Baldwin, J. H., \& Ackerson, A. W. (2017), "Women in the museum: Lessons from the workplace”, Oxford, UK: Taylor \& Francis.

Benjamini, Y., \& Hochberg, Y. (1995), "Controlling the false discovery rate: a practical and powerful approach to multiple testing”, Journal of the Royal Statistical Society. Series B (Methodological), pp. 289-300.

Bettencourt, B., \& Miller, N. (1996), "Gender differences in aggression as a function of provocation: a meta-analysis”, Psychological Bulletin, Vol. 119 No. 3, pp. 422-447.

Benzaquen, S., (2014), "Looking at the Tuol Sleng Museum of genocidal crimes, Cambodia, on Flickr and YouTube”, Media, Culture \& Society, Vol. 36 No. 6, pp.790-809.

Blinde, E. M., \& McCallister, S. G. (2003), "Observations in the National Baseball Hall of Fame and Museum: doing gender in Cooperstown”, Research Quarterly for Exercise and Sport, Vol. 74 No. 3, pp. 301-312.

Bounia, A., Nikiforidou, A., Nikonanou, N., \& Matossian, A. D. (2012), "Voices from the Museum: Survey research in Europe’s national museums”, Linköping University Electronic Press.

Callihan, E., \& Feldman, K. (2018), "Presence and Power: Beyond Feminism in Museums”, Journal of Museum Education, Vol. 43 No. 3, pp. 179-192.

Christensen, H. D. (2016), “A never-ending story: the gendered art museum revisited”, Museum Management and Curatorship, Vol. 31 No. 4, pp. 349-368.

Cincinnatus (2001), "Minneapolis Institute of Arts 2001 visitor survey", available at: http://archive.artsmia.org/UserFiles/File/userfiles/about-the-museum/visitor01.pdf (accessed 20 June 2018).

Coleman, J., \& Nankervis, A. (2015), "The missing link: Volunteers, museums, and researchers in the digital age", International Journal of the Inclusive Museum, Vol. 8 No. 1, pp. 11-23.

Dancu, T. N. (2010), “Designing exhibits for gender equity”, (PhD Thesis). Portland, OR: Portland State University.

Diamond, J. (1994), "Sex differences in science museums: A review”, Curator: The Museum Journal, Vol. 37 No. 1, pp. 17-24.

DiPietro, J. A. (1981), "Rough and tumble play: A function of gender”, Developmental Psychology, Vol. 17 No. 1, pp. 50-58.

Döring, N., \& Mohseni, M. R. (in press), "Male dominance and sexism on YouTube: results of three content analyses", Feminist Media Studies.

Eccles, K., \& Greg, A. (2014), "Your Paintings Tagger: Crowdsourcing descriptive metadata for a national virtual collection”, In: Ridge, M. (Ed). Crowdsourcing our Cultural Heritage. Oxford, UK: Routledge (pp. 185-208).

Eccles, K. (2018), "Lessons from the Museums without Walls: Crowdsourcing to understand public interactions with cultural heritage”, Policy, 2016, 2014.

Fernandes, A. B. (2018), “'But will there be visitors?’ Public outreach efforts using social media and online presence at the Côa Valley Museum and Archaeological Park (Portugal)”, Internet Archaeology, Vol. $47 . \quad$ Available: http://intarch.ac.uk/journal/issue47/5/1.html

Haliliuc, A. (2013), "Who is a victim of communism? Gender and public memory in the Sighet Museum, Romania”, Aspasia, Vol. 7, pp. 108-131.

Halpern, H. P., \& Perry-Jenkins, M. (2016), "Parents' gender ideology and gendered behavior as predictors of children's gender-role attitudes: A longitudinal exploration”, Sex Roles, Vol. 74 No. 11-12, pp. 527-542.

Haran, B., \& Poliakoff, M. (2011), "The periodic table of videos", Science, Vol. 332 No. 6033, pp. 1046-1047. 
Hassett, J. M., Siebert, E. R., \& Wallen, K. (2008), "Sex differences in rhesus monkey toy preferences parallel those of children”, Hormones and Behavior, Vol. 54 No. 3, pp. 359-364.

Heitman, C. C. (2017), "the creation of gender bias in museum collections: Recontextualizing Archaeological and Archival Collections from Chaco Canyon, New Mexico”, Museum Anthropology, Vol. 40 No. 2, pp. 128-142.

Hill, K. (2016), "Women and museums 1850-1914: Modernity and the gendering of knowledge”, Oxford, UK: Oxford University Press.

Hines, M. (2011), "Gender development and the human brain”, Annual Review of Neuroscience, Vol. 34, pp. 69-88.

Holm, S. (1979), “A simple sequentially rejective multiple test procedure”, Scandinavian Journal of Statistics, 46 No. 2, pp. 65-70.

Jarvis, T., \& Pell, A. (2005), "Factors influencing elementary school children's attitudes toward science before, during, and after a visit to the UK National Space Centre", Journal of Research in Science Teaching, Vol. 42 No. 1, pp. 53-83.

Kornienko, O., Santos, C. E., Martin, C. L., \& Granger, K. L. (2016), "Peer influence on gender identity development in adolescence”, Developmental Psychology, Vol. 52 No. 10, pp. 1578-1592.

Kremer, K. B., \& Mullins, G. W. (1992), "Children's gender behavior at science museum exhibits”, Curator: The Museum Journal, Vol. 35 No. 1, pp. 39-48.

Levin, A. K. (ed.) (2010). Gender, sexuality and museums: A Routledge reader. Oxford, UK: Routledge.

Li, Q. (2006), “Cyberbullying in schools: A research of gender differences”, School Psychology International, Vol. 27 No. 2, pp. 157-170.

López Martín, E., \& Morgado Aguirre, B. (2015), "El nuevo público cultural crítico. diseños participativos en los espacios creativos de la web 2.0: El caso de YouTube Play biennial”, Revista de Humanidades, Vol. 31 No. 1, pp. 219-244.

Loxham, A. (2015), "Shaped by familiarity: Memory, space and materiality at Imperial War Museum North”, Museum and Society, Vol. 13 No. 4, pp. 522-538.

Machin, R. (2008), "Gender representation in the natural history galleries at the Manchester Museum”, Museum and Society, Vol. 6 No. 1, pp. 54-67.

Matthes, J., Prieler, M., \& Adam, K. (2016), “Gender-role portrayals in television advertising across the globe”, Sex Roles, Vol. 75 No. 7-8, pp. 314-327.

McHale, S. M., Kim, J. Y., Dotterer, A. M., Crouter, A. C., \& Booth, A. (2009), "The development of gendered interests and personality qualities from middle childhood through adolescence: A biosocial analysis”, Child Development, Vol. 80 No. 2, pp. 482-495.

Merriman, N. (2018), “Accurate data on audience demographics is way forward”, Museums Journal, Vol. 118 No. 2, pp. 14.

Morey Group (2013), "Washington State History Museum: Visitor survey Fall 2013”, available at: http:/www.washingtonhistory.org/files/library/visitor-survey.pdf (accessed 20 June 2018).

Museums Aotearoa (2017), “2017 National Visitor Survey”, available at: http://www.museumsaotearoa.org.nz/sites/default/files/2017_ma_nvs_a3_final.pdf (accessed 20 June 2018).

Nesta, (2015), "Digital Culture 2015: How arts and cultural organisations in England use technology", London, UK: Nesta, available at: http://www.artscouncil.org.uk/sites/default/files/download-file/Digital-Culture-2015Final.pdf (accessed 20 June 2018). 
Newman, M. L., Groom, C. J., Handelman, L. D., \& Pennebaker, J. W. (2008), "Gender differences in language use: An analysis of 14,000 text samples”, Discourse Processes, Vol. 45 No. 3, pp. 211-236.

Oomen, J., Gligorov, R., \& Hildebrand, M. (2014), "Waisda?: making videos findable through crowdsourced annotations”, In: Ridge, M. (Ed). Crowdsourcing our Cultural Heritage. Oxford, UK: Routledge (pp. 161-184).

OSSL (2016), “West Highland Museum Visitors Survey 2016”, available at: http://www.westhighlandmuseum.org.uk/wpcontent/uploads/2017/05/WHM_Survey_Analysis.pdf (accessed 20 June 2018).

O’Reilly, C., \& Lawrenson, A. (2014), "Revenue, relevance and reflecting community: Blockbusters at the Art Galley of NSW", Museum and Society, Vol. 12 No. 3, pp. 157170.

Pedro, A. R. (2010), “Portuguese museums and Web 2.0”, Ciência da Informação, Vol. 39 No. 2, pp. 92-100.

Pelling, M. (2018), “Collecting the world: Female friendship and domestic craft at Bulstrode Park”, Journal for Eighteenth-Century Studies, Vol. 41 No. 1, pp. 101-120,

Pietrobruno, S. (2014), "Between narratives and lists: Performing digital intangible heritage through global media”, International Journal of Heritage Studies, Vol. 20 No. 7-8, pp. 742-759.

Price, C. A., Kares, F., Segovia, G., \& Loyd, A. B. (in press), "Staff matter: Gender differences in science, technology, engineering or math (STEM) career interest development in adolescent youth”, Applied Developmental Science. doi:10.1080/10888691.2017.1398090

Quinlan-Gagnon, W. (2012), “Art museums online: Using interactive websites to build cultural capital. International Journal of the Inclusive Museum, Vol. 5 No. 2, pp. 23-32.

Ramey-Gassert, L. (1996), "Same place, different experiences: Exploring the influence of gender on students' science museum experiences”, International Journal of Science Education, Vol. 18 No. 8, pp. 903-912.

Silber, B., \& Triplett, T. (2015), “A decade of arts engagement: findings from the Survey of Public Participation in the Arts, 2002-2012”, National Endowment for the Arts, available at: https://www.arts.gov/sites/default/files/2012-sppa-feb2015.pdf (accessed 20 June 2018).

Smith, L. F., Smith, J. K., \& Tinio, P. P. (2017), “Time spent viewing art and reading labels”, Psychology of Aesthetics, Creativity, and the Arts, Vol. 11 No. 1, pp. 77-85.

Smithsonian (2004), "Results of the 2004 Smithsonian-wide Survey of Museum Visitors, available at: https://www.si.edu/content/opanda/docs/rpts2004/04.10.visitors2004.final.pdf (accessed 20 June 2018).

Spring, L., Smith, M., \& DaSilva, M. (in press), "The transformative-learning potential of feminist-inspired guided art gallery visits for people diagnosed with mental illness and addiction”, International Journal of Lifelong Education. doi:10.1080/02601370.2017.1406543

Su, R., Rounds, J., \& Armstrong, P. I. (2009), "Men and things, women and people: A metaanalysis of sex differences in interests”, Psychological Bulletin, 135 No. 6, pp. 859-884

Sundjaja, A.S., Gaol, F.L., Abdinagoro, S.B., \& Abbas, B.S. (2017), "The behavior of online museum visitors on Facebook fan page of the museum in Indonesia”, Binus Business Review, Vol. 8 No. 3, pp. 237-243

Sutcliffe, K., \& Kim, S. (2014), "Understanding children's engagement with interpretation at a cultural heritage museum”, Journal of Heritage Tourism, Vol. 9 No. 4, pp. 332-348. 
Swan, S. H., Liu, F., Hines, M., Kruse, R. L., Wang, C., Redmon, J. B., \& Weiss, B. (2010), "Prenatal phthalate exposure and reduced masculine play in boys", International Journal of Andrology, Vol. 33 No. 2, pp. 259-269.

TAA (2014), “Cambridge University Museums benchmarking 2014”, available at: http://www.cam.ac.uk/sites/www.cam.ac.uk/files/ucm_benchmarking_report_2014__final.pdf (accessed 20 June 2018).

Tellhed, U., Bäckström, M., \& Björklund, F. (2017), "Will I fit in and do well? The importance of social belongingness and self-efficacy for explaining gender differences in interest in STEM and HEED majors”, Sex Roles, Vol. 77 No. 1-2, pp. 86-96.

Thelwall, M. \& Mas-Bleda, A. (2018), "YouTube science channel video presenters and comments: Female friendly or vestiges of sexism?”, Aslib Journal of Information Management, Vol. 70 No. 1, pp. 28-46.

Thelwall, M., Wilkinson, D. \& Uppal, S. (2010), "Data mining emotion in social network communication: Gender differences in MySpace”, Journal of the American Society for Information Science and Technology, Vol. 61 No. 1, pp. 190-199.

Thelwall, M. (2018), "Social media analytics for YouTube comments: Potential and limitations”, International Journal of Social Research Methodology, Vol. 21 No. 3, pp. 303-316.

Tunnicliffe, S. D. (1998), “Boy talk/girl talk: is it the same at animal exhibits?”, International Journal of Science Education, Vol. 20 No. 7, pp. 795-811.

Visit Britain (2016), “Annual survey of visits to visitor attractions: Latest results”, available at: https://www.visitbritain.org/annual-survey-visits-visitor-attractions-latest-results (accessed 20 June 2018).

Watson, S., \& Massie, A. (2015), "Making military histories in museums: Editorial introduction”, Museum and Society, Vol. 13 No. 4, pp. 445-446. 